\title{
Application of Direct Analysis in Real Time- Mass Spectrometry (DART-MS) to the Study of Gas-Surface Heterogeneous Reactions: Focus on Ozone and PAHs
}

\author{
Shouming Zhou, Matthew W. Forbes, Jonathan P.D. Abbatt
}

Version Post-print/Accepted Manuscript

\begin{abstract}
Citation Zhou, S., Forbes, M.W., Abbatt, J.P.D., 2015. Application of Direct (published version) Analysis in Real Time-Mass Spectrometry (DART-MS) to the Study of Gas-Surface Heterogeneous Reactions: Focus on Ozone and PAHs. Anal. Chem. 87, 4733-4740. https://doi.org/10.1021/ac504722z.

Copyright / License This document is the Accepted Manuscript version of a Published Work that appeared in final form in Analytical Chemistry, copyright (C) American Chemical Society after peer review and technical editing by the publisher. To access the final edited and published work see https://pubs.acs.org/doi/10.1021/ac504722z.
\end{abstract}

How to cite TSpace items

Always cite the published version, so the author(s) will receive recognition through services that track citation counts, e.g. Scopus. If you need to cite the page number of the author manuscript from TSpace because you cannot access the published version, then cite the TSpace version in addition to the published version using the permanent URI (handle) found on the record page.

This article was made openly accessible by $U$ of $T$ Faculty. Please tell us how this access benefits you. Your story matters. 


\title{
Application of Direct Analysis in Real Time-Mass Spectrometry (DART-MS) to the Study of Gas-Surface Heterogeneous Reactions: Focus on Ozone and PAHs
}

\author{
Shouming Zhou*, Matthew W. Forbes, Jonathan P.D. Abbatt \\ Department of Chemistry, University of Toronto, Toronto, ON, M5S 3H6, Canada \\ * to whom correspondence should be addressed
}

\begin{abstract}
A novel analytical method is presented whereby Direct Analysis in Real Time - Mass Spectrometry (DART-MS) is applied to the study of gas-surface heterogeneous reactions. To illustrate the capabilities of the approach, the kinetics of a well-studied reaction of surface-bound polycyclic aromatic hydrocarbons (PAHs) with ozone are presented. Specifically, using helium as the reagent gas and with the DART heater temperature of $500{ }^{\circ} \mathrm{C}$, nanogram quantities of benzo[e]pyrene $(\mathrm{BeP})$ deposited on the outside of glass melting point capillary tubes were analyzed in positive ion mode with a limit of detection of $40 \mathrm{pg}$. Using bis(2-ethylhexyl) sebacate (BES) as an internal standard, the kinetics of the ozone-BeP reaction were assessed by determining the surface-bound BeP decays, after oxidation in an off-line reaction cell. The reaction is demonstrated to follow the Langmuir-Hinshelwood (L-H) mechanism, known to prevail for heterogeneous reactions of this type. In addition, a wide array of oxygenated, condensed-phase products has been observed. The present work demonstrates the capability of the DART-MS technique to investigate the heterogeneous chemistry taking place on a wide range of surfaces, such as those that form in both outdoor and indoor environments.
\end{abstract}

\section{INTRODUCTION}

Polycyclic aromatic hydrocarbons (PAHs) are a class of air pollutants emitted from incomplete combustion processes, including coal and biomass burning, as well as diesel and gasoline engines. ${ }^{1-3}$ PAHs are also formed in indoor environments from coal and wood combustion, tobacco smoke and food-cooking. ${ }^{4,5}$ PAHs containing three or more benzene rings are of semi- or low-volatility and readily adsorb to surfaces such as soil, water, plants, and indoor and outdoor building surfaces. Recent studies suggest that heterogeneous reactions of surface-bound PAHs are the dominant mechanism of their atmospheric degradation. ${ }^{6,7}$ Moreover, toxicological studies show that the photooxidation products of the PAHs, such as PAH-quinones and nitro-PAHs, can induce the formation of reactive oxygen species (ROS) in the cell and lead to lipid peroxidation and DNA damage. ${ }^{8-10}$ It is therefore important to understand the heterogeneous transformations of surface-bound PAHs.

Despite substantial effort aimed at studying the heterogeneous reactions of PAHs with 
atmospheric oxidants, our understanding of their oxidation kinetics and mechanisms is still incomplete. In part this is due to limitations in the instrumentation available to investigate in situ the composition of the surfaces to which the PAHs can adsorb. As well, the PAH oxidation products are numerous and complex in composition. Early work was conducted by depositing PAHs on different supporting materials, such as filters, silica gel and glass beads, followed by extraction and analysis of the PAHs and oxidation products, using infrared spectroscopy, spectrophotometry or mass spectrometry. ${ }^{11-16}$ The limitation in these studies was the relatively poor separation of the reactants and products, leading to difficulties in quantitative measurement of the PAH decay, as well as in the monitoring of specific reaction products. This issue was resolved by later work with application of gas and liquid chromatography coupled with ultraviolet/fluorescence detection or mass spectrometry. ${ }^{17-20}$ For example, GC and HPLC have been used for studies conducted on a wide variety of surfaces, including those mentioned above, ${ }^{21-34}$ aerosol particles ${ }^{35-38}$ and air-aqueous interfaces. $^{39-42}$ However, since these techniques require extraction and pre-concentration processes, they may result in artifacts in products analysis. ${ }^{43}$ In addition, for some products, such as carbonyls or carboxylic acids, their analysis requires an extra derivatization procedure..$^{44,45}$

Other techniques, such as laser induced fluorescence, ${ }^{46-49}$ diffuse reflectance infrared Fourier transform spectroscopy (DRIFTS), ${ }^{50,51}$ and attenuated total reflection Fourier transform infrared (ATR-FTIR) $)^{52,53}$ have also been applied to studying heterogeneous oxidation of PAHs. PAH degradation kinetics have also been measured by monitoring the depletion of gas-phase oxidants using mass spectrometry ${ }^{54,55}$ and chemiluminescence analyzers; ${ }^{56-59}$ however, this approach suffers due to a lack of reactant specificity and the inability to analyze the oxidation products.

More recently, aerosol mass spectrometry (AMS), such as vacuum ultraviolet photoionization aerosol time-of-flight mass spectrometer (VUV-ATOFMS) ${ }^{60-64}$ and Aerodyne aerosol mass spectrometer (Aerodyne AMS), ${ }^{65,66}$ has been used to investigate PAH heterogeneous oxidation. With aerosol samples directly introduced into the instrument, AMS does not require sample extraction from the condensed phase and pre-concentration. However, this technique is specifically used to study the reactions taking place on aerosol particles, which limits its applications to other surfaces. Moreover, since the Aerodyne AMS evaporates most chemicals in the particles and uses electron ionization (EI) it gives rise to difficulties in product identification.

Direct analysis in real time mass spectrometry (DART-MS) is an atmospheric pressure ionization technique first developed by Cody et al. ${ }^{67}$ Under ambient laboratory conditions, analytes are volatilized directly in front of the sampling aperture of the mass spectrometer by a heated gas flow containing metastable helium (He) atoms. In the positive ion mode of operation, analyte ionization occurs typically via Penning ionization, protonation or ammonium attachment to produce, respectively, 
$\mathrm{M}^{+},[\mathrm{M}+\mathrm{H}]^{+}$and/or $\left[\mathrm{M}+\mathrm{NH}_{4}\right]^{+}$ion species. DART-MS is well suited for the analysis of molecules over a wide range of polarity and has been applied widely in the fragrance, pharmaceutical, food and forensic sciences industries (see a review from Gross $^{68}$ and references therein). DART can also be adapted easily for the analysis of a wide variety of surfaces (such as glass plates, leaves, currency bills, clothes, fruits and vegetables, etc.) and requires little or no sample preparation.

Recently, DART-MS has been used to investigate the composition of organic aerosol particles by introducing a stream of organic particles, such as oleic acid, to the volume between the DART ionization source and the MS inlet. ${ }^{69,70}$ The volatilized molecules from the particle surfaces were ionized and then analyzed by the MS. In this study, we describe the development of an analytical approach using DART-MS that permits the study of the oxidation kinetics and product formation associated with gas-surface heterogeneous reactions occurring on organic films. Whereas the system studied in this paper is ozone reacting with a condensed-phase $\mathrm{PAH}$, benzo[e]pyrene, the same analytical technique could be used to study gas-surface heterogeneous reactions taking place on a wide array of surfaces.

\section{EXPERIMENTAL}

\section{Chemicals and Reagents}

Benzo[e]pyrene (BeP) (98\%, solid), benzo[a]pyrene (BaP) and bis(2-ethylhexyl) sebacate (BES) $(\geq 97 \%$, liquid) were purchased from Sigma-Aldrich (Canada). Acetonitrile and dichloromethane (HPLC grade) were purchased from VWR, Canada. All the chemicals and reagents were used as received.

\section{Generation of BeP and BaP Thin Films}

$\mathrm{BeP}(\sim 50 \mu \mathrm{g} / \mathrm{mL}$ in acetonitrile: dichloromethane $(50: 1 \mathrm{v} / \mathrm{v}))$ and BES $(\sim 50 \mu \mathrm{g} / \mathrm{mL}$ in acetonitrile) stock solutions were mixed and diluted in acetonitrile, making the final concentrations (in $\mu \mathrm{g} / \mathrm{mL}$ ) of BeP and BES to be 1.0 and 0.5 , respectively, for the kinetics study, and 2.0 and 0.5 , respectively, for the product analysis. BES was chosen as an internal standard to quantify the relative amount of BeP on the premise that BES does not react with gas-phase ozone. $\mathrm{BaP}$ films were made in the same manner as those for BeP.

Home-made Teflon capillary holders $(13 \mathrm{~cm}$ long $\times 2 \mathrm{~cm}$ wide $)$ were used to hold 11 glass melting point capillary tubes each. $1 \mu \mathrm{L}$ of the BeP/BES solution was deposited on the sealed, outside end of the glass capillary tubes using a micro-syringe $(10 \mu \mathrm{L}$, SGE Analytical Science) (Figure S1) resulting in absolute amounts of BeP and BES on the capillary of 1.0 and $0.5 \mathrm{ng}$, respectively, for kinetic studies and 2.0 and $0.5 \mathrm{ng}$, respectively, for products analysis. Multiple capillary tubes were used to allow averaging for the signals from each tube. 
After the solvents evaporate, a thin film of BeP with BES forms on the outside of the sealed end of the tubes. If the films were uniformly thick, they would have close to monolayer thickness, i.e. for a film geometric area of $\sim 1 \mathrm{~mm}^{2}$, the surface coverage with $1 \mathrm{ng}$ BeP present would be $\sim 2.4 \times 10^{14}$ molecules $/ \mathrm{cm}^{2}$ for a BeP area of $5 \times 10^{-15}$ $\mathrm{cm}^{2} /$ molecule. However, scanning electron microscope images (not shown) demonstrate that the films have structure, with crystalline $\mathrm{BeP}$ cubes covered in a liquid BES film. As discussed below, when the same amount (1 ng) of $\mathrm{BaP}$, an isomer of BeP, was deposited on the same capillaries, the kinetics showed that $\sim 30 \%$ of the $\mathrm{BaP}$ remained unreacted due to burial, consistent with a non-uniform deposit on the capillary surfaces.

\section{Heterogeneous Oxidation of BeP by Gas-phase Ozone}

After BeP/BES was deposited on the capillaries, the capillary holders were placed into a desiccator where a flow of $\sim 5 \mathrm{slm}$ (standard litre per minute) nitrogen was added to prevent oxidation of the BeP by ambient oxidants and contamination from room air. The oxidation experiments were carried out by placing a capillary holder into a horizontally oriented home-made cylindrical Pyrex glass flow tube (42-cm-long and 6-cm-i.d.) into which an ozone flow was added via a glass inlet. A Teflon frame was placed inside the flow tube to hold the capillary holder (Figure S2). Gas-phase ozone was generated by passing $500 \mathrm{sccm}$ (standard cubic centimeter per minute) of $\mathrm{N}_{2}$ and $\mathrm{O}_{2}$ through an ozone generator that was composed of a quartz cell and a Pen-Ray lamp. A moveable metal cover outside the lamp was used to regulate the ozone formation rate and the ozone concentrations in the flow tube. The residence time of ozone in the flow tube was $\sim 130$ seconds. An air flow $(\sim 1.3 \mathrm{slm})$ was added to the ozone flow at the outlet of the flow tube making a total flow of $1.8 \mathrm{slm}$, from which $\sim 1.5 \mathrm{slm}$ went to a UV photometric $\mathrm{O}_{3}$ analyzer (Thermo Model $\left.49 \mathrm{i}\right)$ and the rest $(\sim 300 \mathrm{sccm})$ was dumped to the exhaust. A kinetic experiment was performed by varying the exposure time of $\mathrm{BeP} / \mathrm{BES}$ samples to ozone by replacing the oxidized capillaries inside the flow tube by a set of non-oxidized ones at different time intervals (from 0 to 90 minutes) such that the ozone concentration remained the same. The oxidized capillaries were stored in the desiccator until DART-MS analysis.

\section{Limit of Detection (LOD) of BeP with DART-MS Analysis}

The LOD of BeP with DART-MS was determined using the calibration curve method. Five different concentrations of $\mathrm{BeP}$ solutions in acetonitrile:dichloromethane $(50: 1=v / v)$ were prepared along with the solvent blank, and $1 \mu \mathrm{L}$ of each solution was added outside the sealed end of the 11 capillaries. The calibration was performed by varying the amount of the BeP in the range of 0-0.1 ng. After the solvent evaporated the samples were analyzed by DART-MS.

\section{DART-MS Analysis}

The instrument used in this work is a JMS-T100LC time-of-flight mass spectrometer (JEOL USA Inc., Peabody,MA) equipped with a DART SVP-100 ion source (IonSense Inc., Saugus, MA) and is located in the Departmental mass spectrometry facility. The 
ion source was operated in the positive ion mode with helium $(\mathrm{He})$ as the reagent gas. The ion source settings were: He flow $3.0 \mathrm{slm}$; He temperature $500{ }^{\circ} \mathrm{C}$; grid electrode voltage $350 \mathrm{~V}$. The configuration of the analytical setup is shown in Figure S3. A Vapur Interface (IonSence Inc.) fitted with a ceramic inlet tube $(0.5 \mathrm{~cm}$ id and $4.1 \mathrm{~cm}$ in length) was mounted between the DART ion source and the MS. One end of the tube was located directly in front of the MS inlet and the other faced the DART ion source (Figure S3). A diaphragm pump was used to maintain the low pressure inside the interface chamber with a needle valve between the pump and the interface used to adjust a total flow through the ceramic tube of $3.8 \mathrm{slm}$. The capillary holder was placed on a motorized linear rail via a stainless steel stand, whose moving speed was controlled by a computer program (DART SVP control software v 3.2.2) and was optimized at $0.3 \mathrm{~mm} / \mathrm{s}$. When the capillary passed between the ceramic tube and the DART ion source, the chemicals on the capillary were desorbed and ionized by the helium flow from the DART ion source. Part of the evaporated/ionized samples $(\sim 1 \mathrm{slm})$ was then taken into the MS inlet via the ceramic tube and the rest was removed from the interface chamber by the diaphragm pump. Considerable effort was expended developing the correct geometry for analysis of BeP/BES films and the arrangement described above provided the optimum sensitivity combined with the best reproducibility.

\section{RESULTS AND DISCUSSION}

\section{DART-MS Analysis of BeP and BES}

Figure 1 shows the time-dependent mass spectrometric signals recorded from 11 capillary tubes mounted on the motorized linear rail moving in front of the DART-MS source before and after 30 minutes ozone (gas phase concentration of $3.4 \times 10^{14}$ molecules $\left./ \mathrm{cm}^{3}\right)$ exposure. The extracted ion chromatograms (XIC) from BeP $(\mathrm{m} / \mathrm{z} 253)$ and BES ( $\mathrm{m} / \mathrm{z} 427$ and 444$)$ are shown in the red and black traces, respectively. Each peak in the ion chromatogram corresponds to one of the 11 samples, and BeP and BES were quantified by integrating each peak area.

As can be seen in Figure 1, the intensity of BES (a) before ozone reaction (average integrated intensity of $8.7 \times 10^{4}$ counts) and (b) after ozone reaction $\left(8.1 \times 10^{4}\right.$ counts) does not change significantly. In contrast, the intensity of $\mathrm{BeP}$ is reduced considerably after 30 minutes ozone oxidation. To quantitatively illustrate this observation, the ratio of [BeP/BES] from each capillary is normalized to the average of 11 [BeP/BES] values from Figure 1 (a) and plotted as blue open circles, where dotted lines are drawn to guide the eye to a [BeP/BES] ratio of 1 . It is clear that the normalized [BeP/BES] signals become lower after ozone exposure (Figure 1 (b)).

Figure 2 (a) shows an average mass spectrum from one sample in positive ion mode. $\mathrm{BeP}\left(\mathrm{MW}\right.$ of $252.09 \mathrm{~g} / \mathrm{mol}$ ) shows a distinct protonated molecule $[\mathrm{M}+\mathrm{H}]^{+}$at $\mathrm{m} / \mathrm{z} 253.10$. It has been reported that some PAHs produce molecular ions $\left(\mathrm{M}^{+\bullet}\right)^{71}$ in addition to $[\mathrm{M}+\mathrm{H}]^{+}$ion species. However, with the source and interface conditions used here, 
$[\mathrm{M}+\mathrm{H}]^{+}$ions from BeP dominate with only a minor molecular ion $[\mathrm{M}]^{+\bullet}$ observed at $\mathrm{m} / \mathrm{z}$ 252.09. In contrast, BES (MW of $426.37 \mathrm{~g} / \mathrm{mol}$ ) shows signals from both $[\mathrm{M}+\mathrm{H}]^{+}$ $\left(\mathrm{m} / \mathrm{z}\right.$ 427.38) and $\left[\mathrm{M}+\mathrm{NH}_{4}\right]^{+}(\mathrm{m} / \mathrm{z}$ 444.41). We found that the ratio between the protonated ion and the ammonium adduct ion for BES varies from experiment to experiment, probably due to fluctuation in the gas-phase ammonia concentration in the room air. Thus, the BES is quantified by the sum of these two ions. The helium temperature was set to the maximum $\left(500{ }^{\circ} \mathrm{C}\right)$ in this work in order to desorb all the substances on the capillaries. Test experiments showed that after the capillary samples were evaporated no observable signals for BeP and BES were seen when the capillaries passed through the hot helium flow a second time.

Figure 2 (b) shows the linearity of $[\mathrm{BeP} / \mathrm{BES}]$ and the $[\mathrm{BeP}]$ intensity as a function of the mass of $\mathrm{BeP}$ applied to the capillaries, when normalized to $1 \mathrm{ng} \mathrm{BeP}$. The uncertainty in each data point is the standard deviation $(\sigma)$ of the 11 capillary tube sample measurements. The use of the BES as an internal standard not only reduces the uncertainties due to varying ion source conditions but also improves the linearity of the response curves.

A kinetic of $\mathrm{BeP}$ reacting with $\mathrm{O}_{3}$ was measured without $\mathrm{BES}$ present and a first-order rate constant of $(1.1 \pm 0.5) \times 10^{-4} \mathrm{~s}^{-1}$ was obtained for $\left[\mathrm{O}_{3}\right]=1.0 \times 10^{14}$ molecules $/ \mathrm{cm}^{3}$. As presented below, within experimental uncertainty a similar rate constant was measured when BES was present, indicating that the presence of BES does not affect the kinetic measurements to a significant extent.

\section{Limit of Detection (LOD) of BeP with DART-MS}

The calibration curve for the determination of the LOD of BeP is shown in Figure S4, where each point again represents an average of 11 measurements and the error bar is the standard deviation $(\sigma)$ of these measurements. The LOD is calculated using the equation: $\mathrm{LOD}=3.3 \sigma / \mathrm{s}$, where $\sigma$ is the standard deviation of the DART-MS response with $\mathrm{BeP}$ close to the LOD, and $\mathrm{s}$ is the slope of the calibration curve in Figure S4. The LOD of BeP with the DART-MS analysis is calculated to be $40 \mathrm{pg}$.

\section{Heterogeneous Kinetics of the PAHs with Gas-phase Ozone}

Figure 3 shows examples of kinetic plots for the reaction of BeP with gas-phase ozone. Each point is an average of 11 sample measurements. Note that the vertical-axes in Figure 3 are normalized $[\mathrm{BeP} / \mathrm{BES}]$ signals. Control experiments $\left(\left[\mathrm{O}_{3}\right]=0\right.$ molecules $/ \mathrm{cm}^{3}$ ) were conducted by turning off the ozone generator and Figure 3 shows that there was no observable loss of $\mathrm{BeP}$ when no ozone is present in the air flow. This confirms that the evaporative losses of both BeP and BES in the flow tube, if any, do not affect the kinetic measurements.

It is clear from Figure 3 that the decays of $10 \mathrm{ng} \mathrm{BeP}$ and $1 \mathrm{ng} \mathrm{BaP}$ level off after $\sim 30$ minutes. The same behavior is apparent, but to a smaller degree, for $1 \mathrm{ng} \mathrm{BeP}$. The leveling-off behaviour for the heterogeneous reactions of PAHs with ozone has been 
observed in previous studies. ${ }^{27,52}$ This observation is thought to be due to multi-layer deposition of solid PAHs on the capillaries whereby surface PAHs react and convert to solid products that remain on the surface and prevent further reaction between ozone and buried PAHs. Our previous study confirmed that solid organic coatings can completely shut off the reaction between ozone and PAHs. ${ }^{65}$ Thicker films, i.e. $10 \mathrm{ng}$ $\mathrm{BeP}$ compared to $1 \mathrm{ng} \mathrm{BeP}$, are more susceptible to this effect because a smaller fraction of the total amount of $\mathrm{PAH}$ is at the surface and available for reaction.

To extract pseudo first-order rate coefficients for just the surface component of the $1 \mathrm{ng}$ $\mathrm{BaP}$ kinetics, we subtract the value of the plateau at long reaction times (i.e. $30 \%$ of the signal) from each data point under the assumption that this material is unavailable for reaction. We then arrive at a linear pseudo first-order decay curve (filled circles in Figure 4). We do the same for $1 \mathrm{ng} \mathrm{BeP}$ data, assuming that either $0 \%$ or $30 \%$ of $\mathrm{BeP}$ is unavailable for surface reaction. The resulting first-order decay curves are shown in blue and red triangles, respectively, in Figure 4 . The differences between the first-order rate coefficients for these two extreme cases vary by factors of 1.6-2.0 for BeP.

The pseudo first-order rate coefficients $\left(k_{1}\right)$ obtained in this manner for $\mathrm{BeP}$ are plotted as a function of ozone concentration in Figure 5, where black and red circles represent the $k_{1}$ obtained with $0 \%$ and $30 \%$ initial $\mathrm{BeP}$ subtraction, respectively, in the data analysis. The non-linear shapes of the plots are consistent with the Langmuir-Hinshelwood (L-H) mechanism:

$k_{1}=\frac{\mathrm{k}_{\max }\left[\mathrm{O}_{3}\right] \mathrm{K}_{\mathrm{O} 3}}{1+\left[\mathrm{O}_{3}\right] \mathrm{K}_{\mathrm{O} 3}}$

where $k_{\max }$ is the maximum pseudo first-order rate coefficient, $\left[\mathrm{O}_{3}\right]$ is the gas-phase ozone concentration and $\mathrm{K}_{\mathrm{O}}$ is the ozone gas-to-surface partition coefficient.

The L-H mechanism assumes that the adsorption of the gas-phase oxidant $\left(\mathrm{O}_{3}\right.$ in this work) cannot be more than a monolayer. ${ }^{73}$ The heterogeneous kinetics between BeP and adsorbed ozone are, therefore, dependent on the gas-phase ozone concentrations and the number of the surface sites to which ozone can adsorb. At low ozone concentrations the adsorbed ozone on the surface should scale linearly with the gas-phase ozone concentrations, leading to a linear increase in the first-order kinetics (Figure 5). When the surface sites are saturated with high levels of ozone, the pseudo first-order rate constants should reach their maxima and be independent of gas-phase ozone concentrations, as can be seen from the plateau at high level of ozone in Figure 5.

Two parameters, $k_{\max }$ and $\mathrm{K}_{\mathrm{O}}$, can be derived by fitting each data set in Figure 5 with Eq1. Listed in Table 1 are the values of the parameters derived from the above mentioned two extreme cases, where the uncertainty represents one standard deviation. While $\mathrm{BeP}$ is known to be a less reactive $\mathrm{PAH}$ towards atmospheric oxidants in 
comparison to $\mathrm{BaP}$ and anthracene (ATC) ${ }^{74,75}$, as can be seen in Table 1, Ringuet et al. ${ }^{31}$ qualitatively reported facile heterogeneous degradation of $\mathrm{BeP}$ by exposing aerosol particles collected at a traffic site in Paris to gas-phase ozone. An early study of Perraudin et al. ${ }^{74}$ reported a linear increase in $k_{1}$ with ozone when BeP was deposited on graphite and silica particles. In Figure 5 of Perraudin et al.'s work ${ }^{74}$, at ozone concentration of $\sim 3.3 \times 10^{14}$ molecules $/ \mathrm{cm}^{3}, k_{1}$ is $\sim 4 \times 10^{-3} \mathrm{~s}^{-1}$ for BeP on graphite particles, almost an order of magnitude higher than the $k_{\max }$ of the present work at a similar level of ozone. These differences could be due to the different substrates on which the $\mathrm{BeP}$ was deposited. In particular, the oxidation kinetics of $\mathrm{BaP}$ on soot particles is known to be significantly faster than on organic aerosol. ${ }^{35,36}$

The kinetic results on the heterogeneous oxidation of $\mathrm{BeP}$ with ozone are compared in Table 1 to the L-H reactivity of phenanthrene and ATC on a variety of surfaces. The maximum pseudo first-order rate coefficients $\left(k_{\max }\right)$ for phenathrene and $\mathrm{BeP}$ exhibit similar reactivity towards ozone if the uncertainties are taken into account and are much lower than for ATC in general, except for the study of Ma et al. ${ }^{52}$ who deposited ATC on Asian dust and Kahan et al. ${ }^{47}$ who deposited ATC on water with a monolayer of hexanoic acid present (Table 1). The reason for the lower $k_{\max }$ value for ATC on Asian dust was not given by the authors, whereas that for ATC/hexanoic acid+water system was attributed to the lower ozone partition coefficient (Коз) for this system.

It appears that the $k_{\max }$ values for ATC deposited on particles are higher than those for flat surfaces (Table 1). The similar trend was also observed by Kwamena et al. ${ }^{37}$ who found that the decay of ATC on aerosol particles were faster than that on flat surfaces. These observations indicate that the surface geometry (flat surface or curved particle) may play a role in the heterogeneous oxidation of PAHs. On the other hand, the different $k_{\max }$ values for ATC in different systems in Table 1 may also be a result of the different techniques used to obtain the kinetic parameters.

\section{Products from Heterogeneous Reaction of $\mathrm{BeP}$ with Ozone}

Figure 6 shows the mass spectrum of the products from the heterogeneous reaction of BeP with gas-phase ozone. The product mass spectrum is obtained by subtracting the reactant spectrum from that recorded after 60 minutes oxidation. Based on the observed mass-to-charge ratios $(\mathrm{m} / \mathrm{z})$ and previous work on the products of ozonolysis of $\mathrm{BaP}$, pyrene and anthracene, several possible ozonolysis products are listed in Table 2. Classes of products, including epoxides, ${ }^{13}$ quinones, diphenols, dialdehydes and dicarboxylic acids, have been reported from photooxidation of other PAHs. ${ }^{7}$ However, this is the first investigation of the product formed by heterogeneous oxidation of BeP by ozone.

It has been reported that lactones are formed by ozonolysis of $\mathrm{BaP}^{78}$ and pyrene; ${ }^{45}$ the most intense peak at $\mathrm{m} / \mathrm{z} 271.08$ in Figure 6 is consistent with product 1 as a major product from ozone reaction with $\mathrm{BeP}$ (Table 2). Other peaks are suggestive of 
formation of quinones with $\mathrm{m} / \mathrm{z} 283.08$ (product 2) and diphenols or dialdehydes with $\mathrm{m} / \mathrm{z} 285.09$ (product 3), but are formed with lower intensities.

With the high sensitivity of DART-MS it was also possible to obtain information on the evolution of the reaction products. From Figure 7 (a) it can be seen that BeP reacts relatively fast in the beginning followed by a slower reaction after $\sim 30$ minutes ozone exposure. Meanwhile, the quinone $(\mathrm{m} / \mathrm{z} 283.08)$ production is only observed in the first 30 minutes and then almost levels-off. This observation indicates that the quinones may be early generation products, as suggest by previous studies of the ozone reaction with ATC $^{27}$ and pyrene. ${ }^{45}$ By contrast, the lactone signal ( $\left.\mathrm{m} / \mathrm{z} 271.08\right)$ increases linearly throughout the course of the reaction. From these data we cannot determine whether this lactone species is an early or late generation oxidation product; however, we note that in the formation mechanism of 4-oxapyrene-5-one Miet et al. ${ }^{45}$ proposed that this lactone was produced via further reaction of primary products from the heterogeneous ozonolysis of pyrene. The product with $\mathrm{m} / \mathrm{z} 303.09$ also appears to be a later generation product. Other products, such as those with $\mathrm{m} / \mathrm{z} 257.10,255.08$ and 239.09 in Figure 6 remain unidentified, but their lower molecular masses compared to BeP suggest that they should be formed from the ring-opening reactions followed by some degree of fragmentation.

We note that the loss of signal from BeP is associated with increasing signal from the reaction products (as represented by the integrated signals from the products with $m / z$ labeled in Figure 6 ), so that the total signal from these species remains relatively unchanged throughout the reaction (Figure 7(b)). This indicates that the relative ionization efficiencies of the reactant and products are similar.

\section{CONCLUSIONS}

This paper presents a new analytical method employing DART-MS to study surface composition and heterogeneous oxidation chemistry. The utility of this sensitive, flexible and quantitative analytical approach has been demonstrated for the oxidation of PAH by ozone.

Key features of the method are: 1. Extremely efficient and rapid analysis of heterogeneous kinetics; 2 . Use of an unreactive internal standard to normalize for variations in the ion-molecule reaction conditions; 3. Measurements of reaction products, particularly oxygenated species that can otherwise only be detected after solvent extraction and perhaps derivitization or chromatographic separation; 4. Volatilization of the entire amount of deposited reactant lead to the low detection limits for PAHs, such as that for BeP in the 10's of pg level; 5. A large number (11) of capillary tubes enhances precision of the measurement. The overall validation of this analytical method is provided by the excellent form of the Langmuir-Hinshelwood kinetics curve shown in Figure 5 and the reaction products suggested in Table 2. 
This new analytical approach complements other methods reported in the literature for measurements of this type. In particular, this approach expands the analytical capabilities to analyze condensed-phase chemicals on macroscopic surfaces in an on-line manner, whereas real-time heterogeneous chemistry studies have only been conducted with aerosol particle samples in the past. ${ }^{60-66,69,70}$ This approach will therefore be of considerable value for studying the chemical processing of films that are present on both outdoor and indoor surfaces. Because DART is a relatively 'soft' form of ionization yielding intact ions with minimal fragmentation, it is possible to obtain molecular weight information of the reaction products that is not so easily obtained when electron ionization (EI) is applied. ${ }^{65,66}$ While reactants such as PAHs are readily detected by off-line techniques such as GC-MS, these techniques do not permit the simultaneous monitoring of many oxygenated reaction products, which invariably form in heterogeneous oxidation studies. We note that this paper provides a complement to the work of Nah et al., which used DART-MS to successfully study organic aerosol chemistry. ${ }^{69,70}$

A potential improvement to the method would be better control over the atmospheric environment of the ion source. This could be achieved by building a vented housing around the ion source through which only clean air, at a controlled relative humidity, passes. Such an environment may make the use of an internal standard unnecessary. This modification was not possible for this work because the mass spectrometer used is housed in a departmental analytical facility. With a dedicated mass spectrometer, one could envisage performing the oxidation studies in a directly-coupled reaction cell.

\section{ACKNOWLEDGEMENTS}

The authors would like to acknowledge funding from the Sloan Foundation. S.Z. thanks Ms. Michelle Young and Mr. Chung Woo Fung for their assistance in DART-MS operation.

Supporting Information Available.

This information is available free of charge via the Internet at http://pubs.acs.org/.

The authors declare no competing financial interest. 


\section{REFERENCES}

(1) Masclet, P.; Cachier, H.; Liousse, C.; Wortham, H. J. Atmos. Chem. 1995, 22, 41-54.

(2) Hays, M.D.; Fine, P.M.; Geron, C.D.; Kleeman, M.J.; Gullett, B.K. Atmos. Environ. 2005, 39, 6747-6764.

(3) Nizzetto, L.; Lohmann, R.; Gioia, R.; Jahnke, A.; Temme, C.; Dachs, J.; Herckes, P.; Di Guardo, A.; Jones, K.C. Environ. Sci. Technol. 2008, 42, 1580-1585.

(4) Naumova, Y.Y.; Eisenreich, S.J. Environ. Sci. Technol. 2002, 36, 2552-2559.

(5) Larsson, B. K.; Sahlberg, G.P.; Eriksson, A.T.; Busk, L.A. J. Agric. Food Chem. 1983, 31, 867-873.

(6) Finlayson-Pitts, B.J., Pitts, J.N., Chemistry of the Upper and Lower Atmosphere. Academic Press, Toronto, 2000.

(7) Keyte, I. J.; Harrison, R.M.; Lammel, G. Chem. Soc. Rev. 2013, 42, 9333-9391.

(8) Van Cauwenberghe, K.; Van Vaeck, L. Mutation Res. 1983, 116, 1-20.

(9) Pitts, Jr. J.N. Environ. Health Persp. 1983, 47, 115-140.

(10) Fu, P.P.; Xia, Q.; Sun, X.; Yu, H. J. Environ. Sci. Health C Environ. Carcinog. Ecotoxicol Rev. 2012, 30, 1-41.

(11) Flak, H.L; Markul, I.; Kotin, P. Aromat. Hydrocarbons, 1955, 13-17.

(12) Pierce, R.C.; Katz, M. Environ. Sci. Technol. 1976, 10, 45-51.

(13) Pitts, Jr. J.N.; Van Cauwenberghe, K.A.; Grosjean, D.; Schmid, J.P.; Fitz, D.;

Belser, W.L.; Knudson, G.B.; Hynds, P.M. Science, 1978, 20, 515-519.

(14) Inscoe, M.N. Anal. Chem. 1964, 36, 2505-2506.

(15) Issaq, H.J.; Andrew, A.W.; Janini, G.M.; Barr, E.W. J. Liquid Chromatogr. 1979, 2, 319-325.

(16) Cimberle, M.R.; Bottino, P.; Valerio, F. Chemosphere, 1983, 12, 317-324.

(17) Fox, M.A.; Olive, S. Science, 1979, 205, 582-583.

(18) Korfmacher, W.A.; Natusch, D.F.S.; Taylor, D.R.; Mamantov, G.; Wehry, E.L. Science, 1980, 207, 763-765.

(19) Pitts, Jr. J.N.; Lokensgard, D.M.; Ripley, P.S.; Van Cauwenberghe, K.A; Van Vaeck, L.; Shaffer, S.D.; Thill, A.J.; Belser, Jr. W.L. Science, 1980, 210, 1347-1349.

(20) Behymer T.D.; Hites, R.A. Environ. Sci. Technol. 1983, 19, 1004-1008.

(21) Pitts, Jr. J.N.; Sweetman, J.A.; Zielinska, B.; Atkinson, R.; Winer, A.M.; Harger, W.P. Environ. Sci. Technol. 1985, 19, 1115-1121.

(22) Kalkwarf, D.R. Environ. Sci. Technol. 1987, 21,643-438

(23) Kamens, R.M.; Guo, Z.; Fulcher, J.N.; Bell, D.A. Environ. Sci. Technol. 1988, 22, 103-108.

(24) Kamens, R.M.; Guo, J.; Guo, Z.; McDow, S.R. Atmos. Environ. 1990, 24A, 1161-1173.

(25) Fan, Z.; Kamens, R.M.; Zhang, J.; Hu, J. Environ. Sci. Technol. 1996, 30, 2821-2827. 
(26) Esteve, W.; Budzinski, H.; Villenave, E. Polycyclic Aromat. Hydrocarbons, 2003, 23, 441-456.

(27) Kwamena, N.-O.A.; Earp, M.E.; Young, C.J.; Abbatt, J.P.D. J. Phys. Chem. A 2006, 110, 3638-3646.

(28) Miet, K.; Budzinski, H.; Villenave, E. Polycyclic Aromat. Compd., 2009, 29, 267-281.

(29) Bedjanian, Y.; Nguyen, M.L. Chemosphere, 2010, 79, 387-393.

(30) Ma, J.; Liu, Y.; He, H.; Atmos. Environ. 2010, 44, 4446-4453.

(31) Ringuet, J.; Albinet, A.; Leoz-Garziandia, E.; Budzinski, H.; Villenave, E. Atmos. Environ. 2012, 61, 15-22.

(32) Zimmermann, K.; Jariyasopit, N.; Simonich, S. L. M.; Tao, S.; Atkinson, R.; Arey, J. Environ. Sci. Technol. 2013, 47, 8434-8442.

(33) Jariyasopit, N.; McIntosh, M.; Zimmermann, K.; Arey, J.; Atkinson, R.; Cheong, P.H.Y.; Carter, R.G.; Yu, T.W. Environ. Sci. Technol. 2014, 48, 412-419.

(34) Ray, D.; Liskova, H.; Klan, P. Environ. Sci.: Processes Impacts, 2014, 16, 770-776.

(35) Poeschl, U.; Letzel, T.; Schauer, C.; Niessner, R. J. Phys. Chem. 2010, 105, 4029-4041.

(36) Kwamena, N.-O.A.; Thornton, J.A.; Abbatt, J.P.D. J. Phys. Chem. A 2004, 108, 11626-11634.

(37) Kwamena, N.-O. A.; Staikova, M. G.; Donaldson, D. J.; George, I. J.; Abbatt, J. P. D. J. Phys. Chem. A 2007, 111, 11050-11058.

(38) Zhang, Y.; Yang, B.; Meng, J.; Gao, S.; Dong, X.; Shu, J. Atmos. Environ. 2010, 44, 697-702.

(39) Mmereki, B.T.; Donaldson, D.J.; Gilman, J.B.; Eliason, T.L.; Vaida, V. Atmos. Environ. 2004, 38, 6091-6103.

(40) Clifford, D.; Donaldson, D.J.; Obrigante, M.; D’Anna, B.; George, C. Environ. Sci. Technol. 2008, 42, 1138-1143.

(41) Henderson, E. A.; Donaldson, D. J. J. Phys. Chem. A 2012, 116, 423-429.

(42) Styler, S.A.; Loiseaux, M.-E.; Donaldson, D.J. Atmos. Chem. Phys., 2011, 11, $1243-1253$.

(43) Sauret-Szczepanski, N.; Lane, D.A. Polycycl. Aromat. Compd., 2004, 24, 161-172.

(44) Perraudin, E.; Budzinsk, H.; Villenave, E. Atmos. Environ. 2007, 41, 6005-6017.

(45) Miet, K.; Menach, K.L.; Flaud, P.M.; Budzinski, H.; Villenave, E. Atmos. Environ. 2009, 43, 3699-3707.

(46) Mmereki, B.T.; Donaldson, D.J. J. Phys. Chem. A 2003, 107, 11038-11042.

(47) Kahan, T.F.; Kwamena, N.-O.A. Doanldson, D.J. Atmos. Environ. 2006, 40, 3448-3459.

(48) Kahan, T.F.; Donaldson, D.J. Environ. Res. Lett. 2008, 3, 045006, doi:10.1088/1748-9326/3/4/045006.

(49) Styler,S.A.; Brigante, M.; D’Anna, B.; George, C.; Donaldson, D.J. Phys. Chem. Chem. Phys. 2009, 11, 7876-7884. 
(50) Kwamena, N.-O.A.; Abbatt, J.P.D. Atmos. Environ. 2008, 42, 8309-8314.

(51) Ma, J.; Liu, Y.; He, H. Atmos. Environ. 2011, 45, 917-924.

(52) Ma, J.; Liu, Y.; Ma, Q.; Liu, C.; He, H. Atmos. Environ. 2013, 72, 165-170.

(53) Han, C.; Liu, Y.; Ma, J.; He, H. Proc. Natl. Acad. Sci. 2012, 109, 21250-21255.

(54) Mak, J.; Gross, S.; Bertram, A.K. Geophys. Res. Lett. 2007, 34, L10804, doi:10.1029/2007GL029756.

(55) Knopf, D.A.; Forrester, S.M.; Slade, J.H. Phys. Chem. Chem. Phys. 2011, 13, 21050-21062.

(56) Brigante, M.; Cazoir, D.; D’Anna, B.; George, C.; Donaldson, D.J. J. Phys. Chem. A 2008, 112, 9503-9508.

(57) Ammann, M.; Donaldson, D.J.; George, C. Proc. Natl. Acad. Sci. 2010, 107, 6605-6609.

(58) Nguyen, M.L.; Bedjanian, Y.; Guilloteau,A. J. Atmos. Chem. 2009, 62,139-150.

(59) Romanias, M.N.; Bedjanian, Y.; Zaras, A.M.; Andrade-Eiroa, A.; Shahla, R.; Dagaut, P.; Philippidis, A. J. Phys. Chem. A, 2013, 117, 12897-12911.

(60) Gloaguen, E.; Mysak, E.R.; Leone, S.R.; Ahmed, M.; Wilson, K.R. Inter. J. Mass. Spec. 2006, 258, 74-85.

(61) Zhang, Y.; Yang, B.; Gan, J.; Liu, C.; Shu, X.; Shu, J. Atmos. Environ. 2011, 45, 2515-2521.

(62) Liu, C.; Zhang, P.; Yang, B.; Wang, Y.; Shu, J. Environ. Sci. Technol. 2012, 46, 7575-7580.

(63) Zhang, Y.; Shu, J.; Liu, C.; Zhang, Y.; Yang, B.; Gan, J. Atmos. Environ. 2013, 68, 114-119.

(64) Zhang, P.; Wang, Y.; Yang, B.; Liu, C.; Shu, J. Chemosphere 2014, 99, 34-40.

(65) Zhou, S.; Lee, A. K. Y.; McWhinney, R. D.; Abbatt, J. P. D. J. Phys. Chem. A 2012, 116, 7050-7056.

(66) Zhou, S.; Shiraiwa, M.; McWhinney, R. D.; Pöschl, U.; Abbatt, J.P.D. Faraday Discus. 2013, 165, 391-406.

(67) Cody, R.B.; Laramée, J.A.; Durst, H.D. Anal. Chem. 2005, 77, 2297-2302.

(68) Gross, J.H. Direct analysis in real time - a critical review on DART-MS. Anal. Bioanal. Chem. 2014, 406, 63-80.

(69) Nah, T.; Chan, M.; Leone, S. R.; Wilson, K. R. Anal. Chem., 2013, 85, 2087-2095.

(70) Chan, M.; Nah, T.; Wilson, K.R. Analyst, 2013, 138, 3749-3757.

(71) Rummel, J.L.; McKenna, A.M.; Marshall, A.G.; Eyler, J.R.; Powell, D.H. Rapid Commun. Mass Spectrom. 2010, 24: 784-790.

(72) Chernetsova, E.S.; Morlock, G.E.; Revelsky, I.A. Russ. Chem. Rev., 2011, 80, 235-255.

(73) Atkins, P.W. Physical Chemistry, $5^{\text {th }}$ Ed.: W.H. Freeman and Company: New York, 1994.

(74) Perraudin, E.; Budzinski, H.; Villenave, E. J. Atmos. Chem. 2007, 56, 57-82;

(75) Butler, J.D.; Crossley, P. Atmos. Environ. 1981, 15, 91-94.

(76) Najera, J.J.; Wamsley, R.; Last, D.J.; Leather, K.E.; Percival, C.J.; Horn, A.B. Intern. J. Chem. Kinet. 2011, DOI 10.1002/kin. 
(77) Letzel, T.; Rosenberg, E.; Wissiack, R..; Grasserbauer, M.; Niessner, R. J. Chromatogr. A 1999, 855, 501-514.

\section{FIGURES AND TABLES}
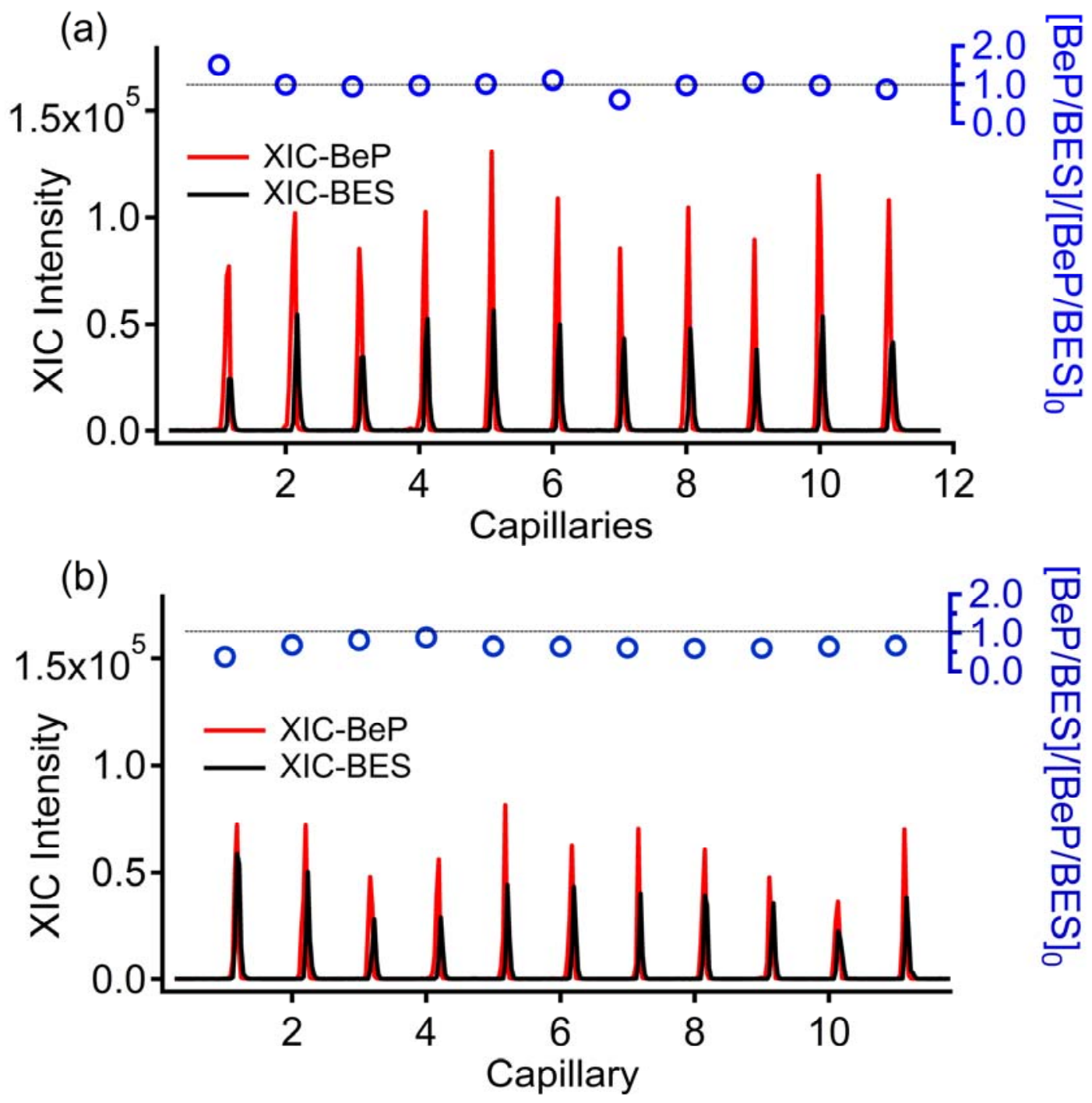

Figure 1. Extracted ion chromatograms (XIC) obtained from 11 capillary samples under positive ion mode for the BeP (red trace) and BES (black trace) and normalized $\mathrm{BeP} / \mathrm{BES}$ (blue circles) before (a) and after (b) 30 minutes ozone (gas phase concentration $=3.4 \times 10^{14}$ molecules $/ \mathrm{cm}^{3}$ ) exposure. The dotted lines represent normalized $\mathrm{BeP} / \mathrm{BES}$ at 1 and correspond to the right-hand-side y axis (see text for explanation). 

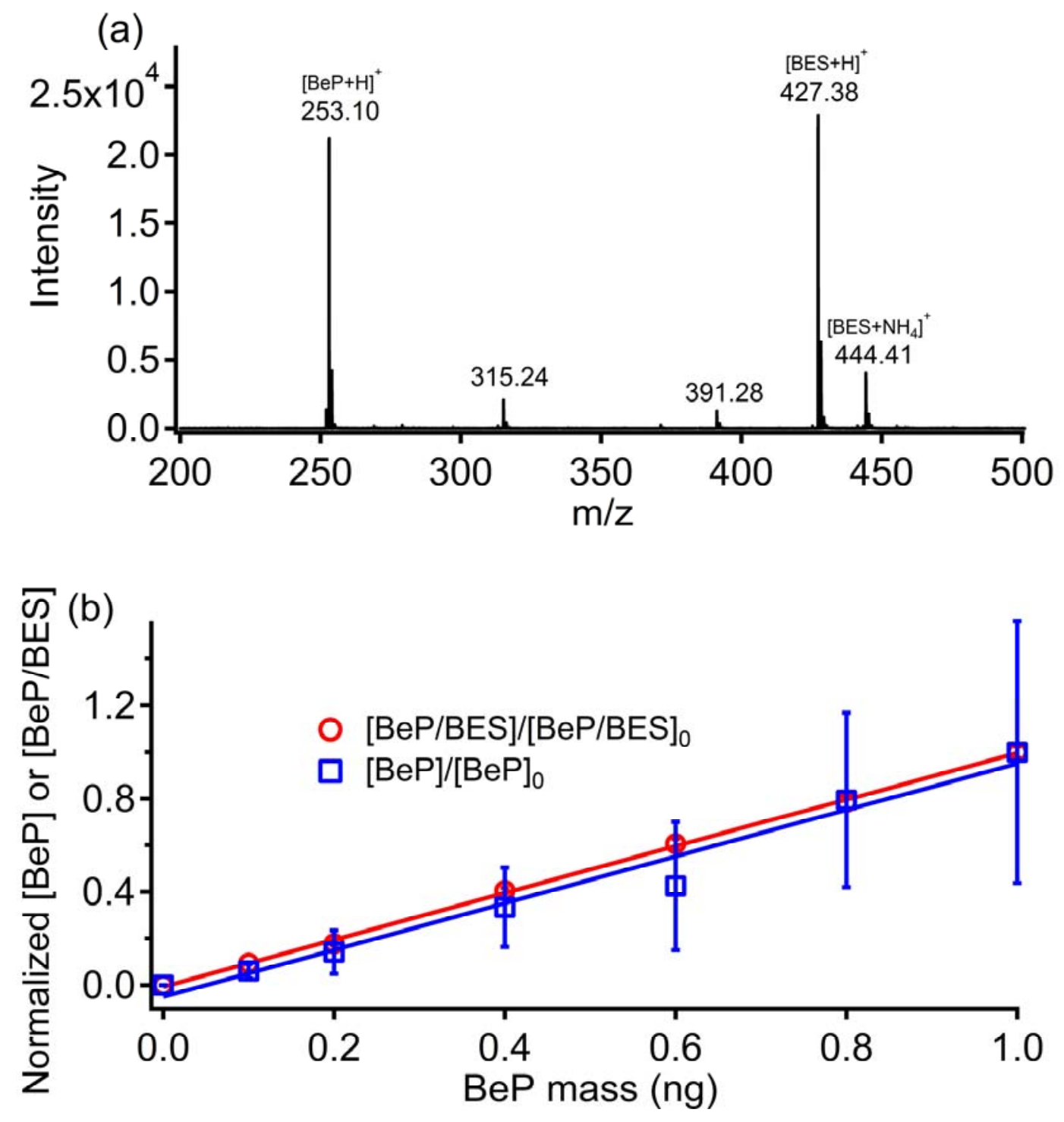

Figure 2. (a) DART mass spectrum for BeP and BES and (b) plot illustrating the linearity of the ratio of the $\mathrm{BeP}$ and $\mathrm{BES}$ signals ( $[\mathrm{BeP} / \mathrm{BES}]$, red circle, $\mathrm{R}^{2}=0.999$ ) and the BeP signal ([BeP], blue square, $\mathrm{R}^{2}=0.973$ ) as a function of $\mathrm{BeP}$ mass, when the signals are normalized to the values for $1 \mathrm{ng} \mathrm{BeP}$. 


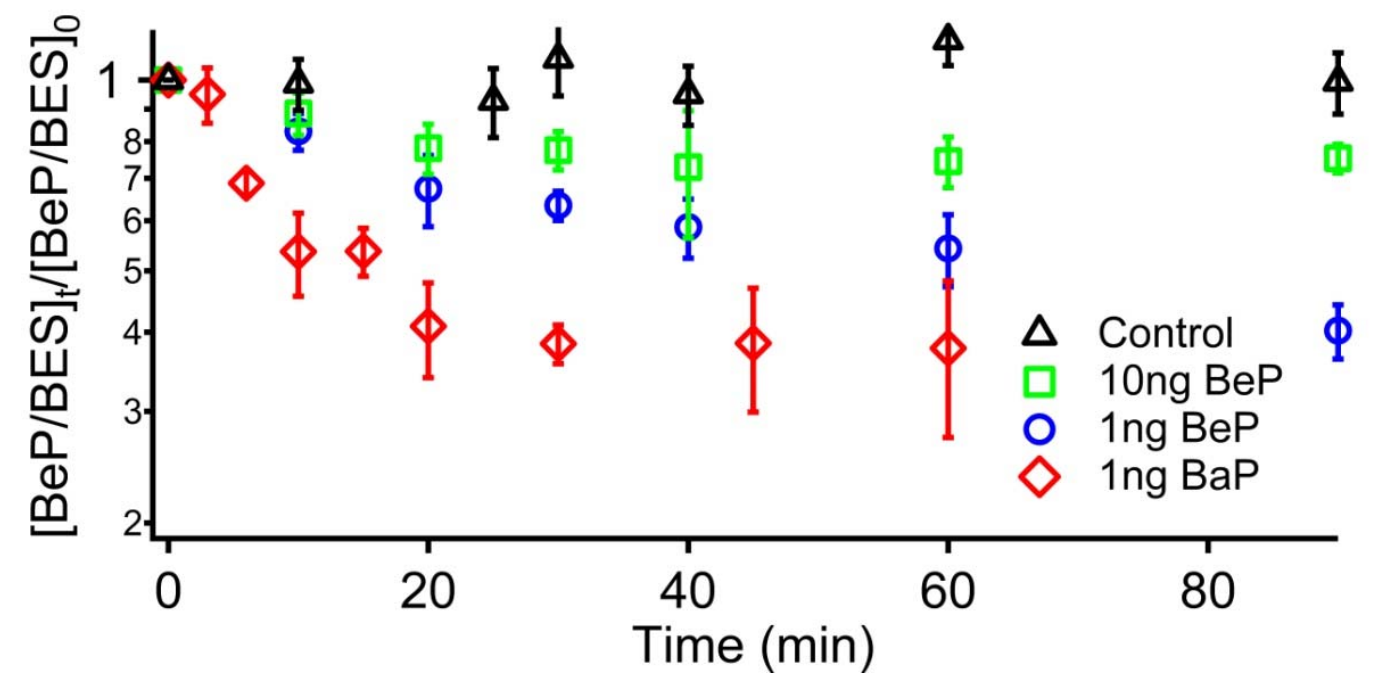

Figure 3. Examples of kinetic plots for the heterogeneous reaction of $\mathrm{BeP}$ and $\mathrm{BaP}$ with ozone. Conditions: $1 \mathrm{ng}$ BeP control (black triangle), $\left[\mathrm{O}_{3}\right]=0$ molecules $/ \mathrm{cm}^{3} ; 10$ $\mathrm{ng}$ (green square) and $1 \mathrm{ng} \mathrm{BeP}$ (blue circle), $\left[\mathrm{O}_{3}\right]=3.4 \times 10^{14}$ molecules $/ \mathrm{cm}^{3} ; 1 \mathrm{ng} \mathrm{BaP}$ (red diamond), $\left[\mathrm{O}_{3}\right]=2.5 \times 10^{12}$ molecules $/ \mathrm{cm}^{3}$. The uncertainty in each point was taken as one standard deviation of the 11 measurements.

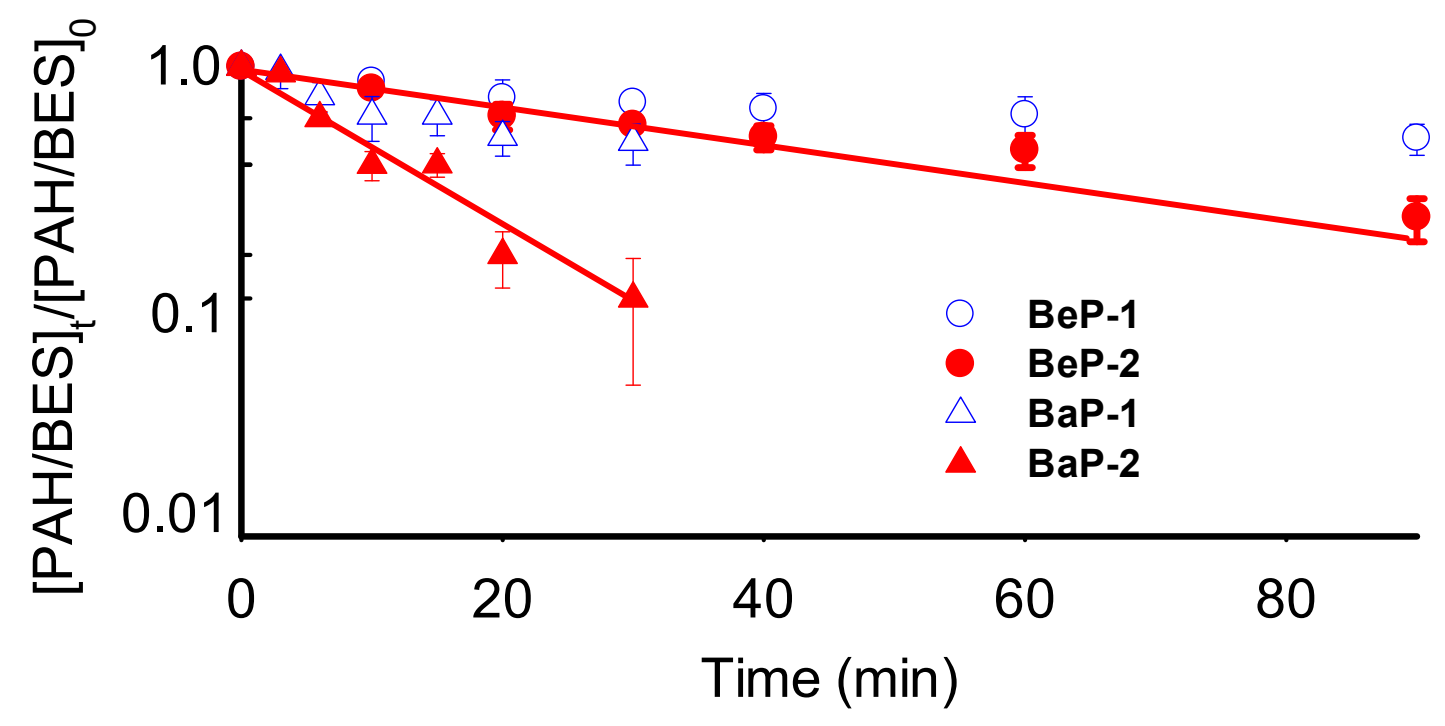

Figure 4. Linear first-order decay curves for $1 \mathrm{ng} \mathrm{BeP}$ (circle) and $\mathrm{BaP}$ (triangle). BeP-1 (open circle) and BaP-1 (open triangle) plot raw data from Figure 3, while the data for BeP-2 (filled circle) and BaP-2 (filled triangle) have been obtained by subtracting the value of the plateau at long reaction times (i.e. $30 \%$ of the signal) from the raw data in Figure 3. 


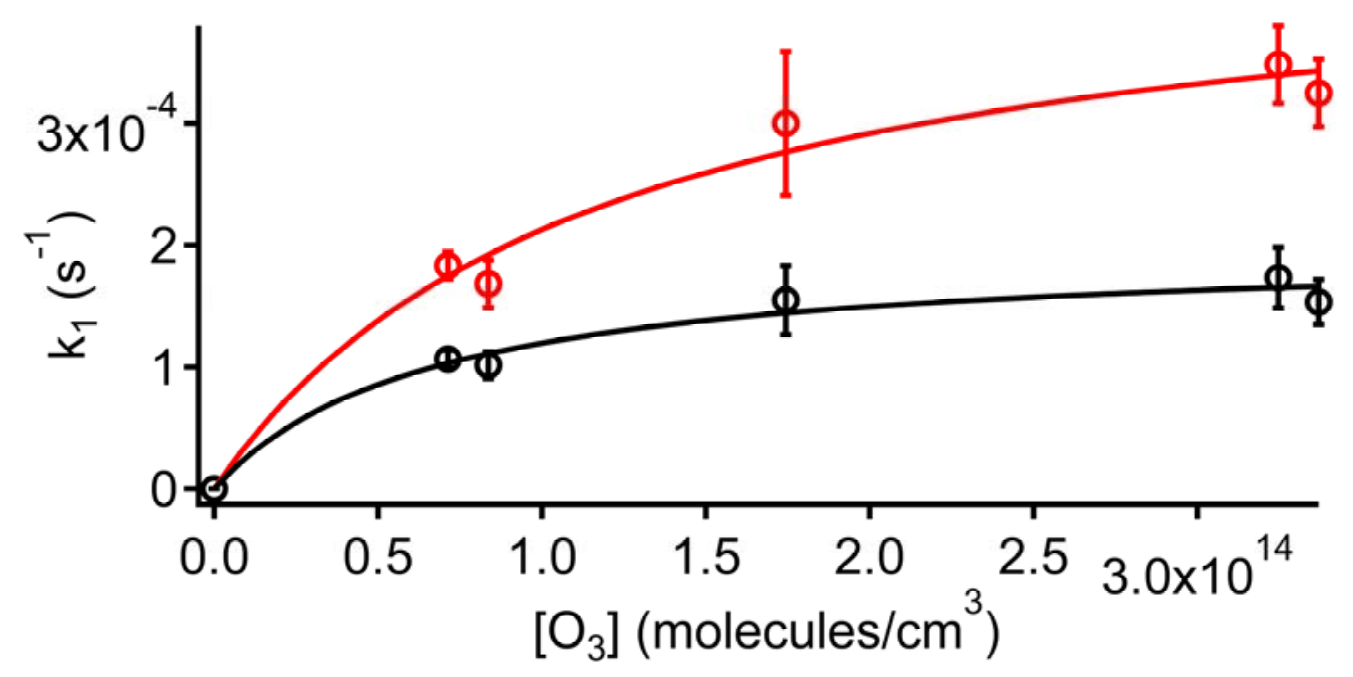

Figure 5. Plots of pseudo-first-order rate coefficients $k_{1}$ as a function of gas-phase ozone concentrations for the heterogeneous reaction of $\mathrm{BeP}$ with ozone. The plot was fitted using a non-linear least-squares fit of Eq 1.

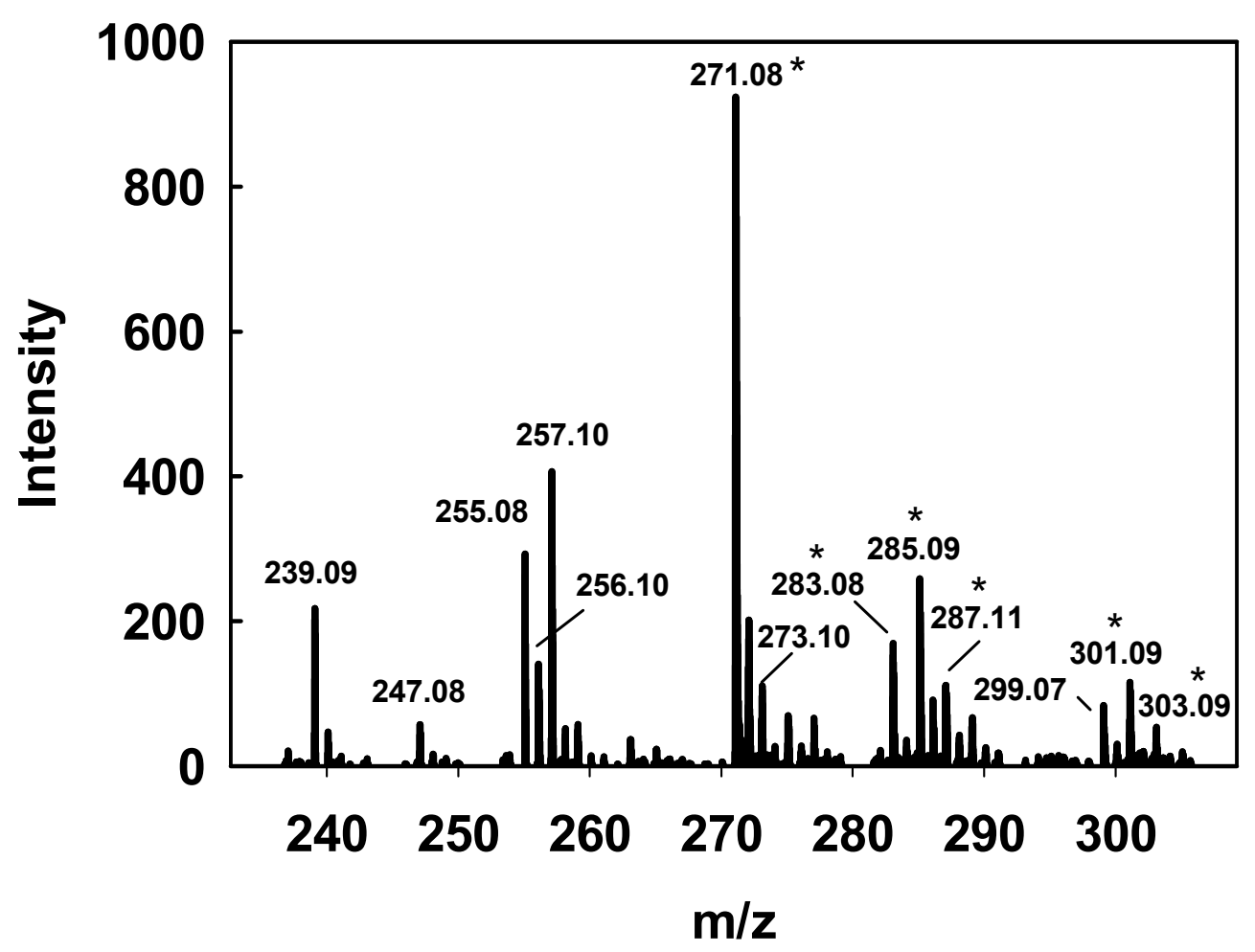

Figure 6. DART mass spectrum for products from heterogeneous reaction of $2 \mathrm{ng} \mathrm{BeP}$ with ozone (the products labelled with a $*$ are suggested in Table 2). 

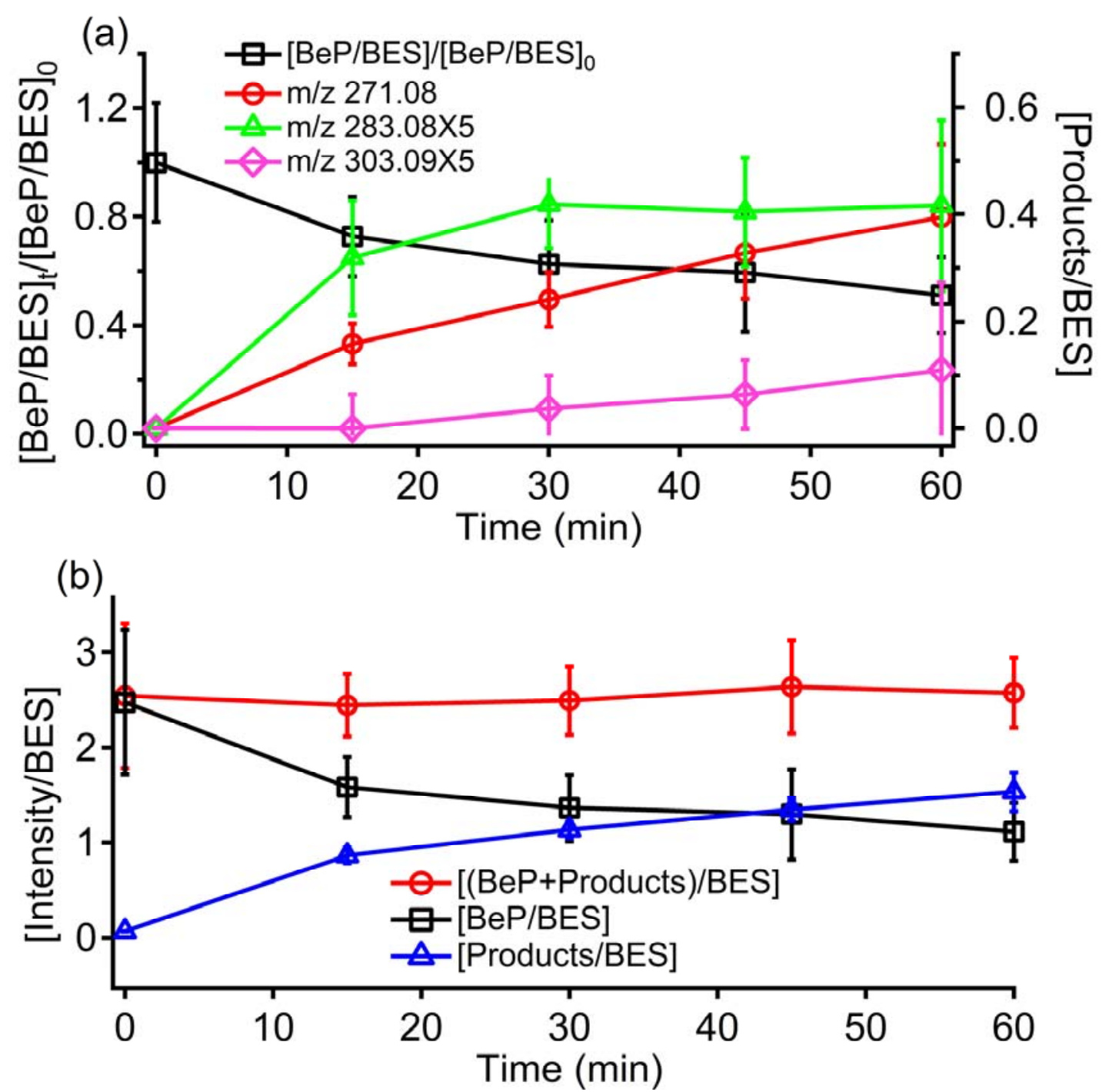

Figure 7. (a) Evolution of the reaction products from ozone reaction with BeP; (b) Integrated signals for BeP, products (with $m / z$ labeled in Figure 6) and the sum of BeP and product signals, as a function of reaction time and normalized to BES. Note that the signals for m/z 283.08 and 303.09 in Figure 7 (a) were scaled by a factor of 5 for better comparison. 
Table 1. Comparison of the results from the present work and previous studies of the heterogeneous reaction of surface-bound PAHs with gas-phase ozone at room temperature.

\begin{tabular}{|c|c|c|c|}
\hline PAH $^{\text {a) }}$ & $k_{\max }\left(10^{-4} \mathrm{~s}^{-1}\right)$ & $K_{O 3}\left(10^{-15} \mathrm{~cm}^{3}\right)$ & Ref. \\
\hline ATC/phenylziloxane oil ${ }^{\text {b) }}$ & $100 \pm 30$ & $100 \pm 40$ & 37 \\
\hline ATC/azelaic acid $^{\text {b) }}$ & $570 \pm 90$ & $2.2 \pm 0.9$ & 37 \\
\hline ATC/Asian dust & $6.1 \pm 0.6$ & $330 \pm 162$ & 52 \\
\hline ATC/(NH 4$)_{2} \mathrm{SO}_{4}$ particles & $350 \pm 160$ & $0.14 \pm 0.17$ & 77 \\
\hline ATC/water & $25.5 \pm 1.7$ & $0.5^{\mathrm{c})}$ & 46 \\
\hline ATC/steric acid+water & $22.6 \pm 2.0$ & $0.5^{\mathrm{c})}$ & 39 \\
\hline ATC/1-octanol+water & $25.9 \pm 1.4$ & $2.0^{\mathrm{c})}$ & 39 \\
\hline ATC/octanoic acid+water & $11.1 \pm 1.2$ & $1.6^{\mathrm{c})}$ & 39 \\
\hline ATC/hexanoic acid+water & $4.8 \pm 0.7$ & $0.9^{\mathrm{c})}$ & 39 \\
\hline ATC/octanol & $25 \pm 1.0$ & $0.6^{\mathrm{c})}$ & 47 \\
\hline phenanthrene/decanol & $5.0 \pm 3.0$ & $0.5^{\mathrm{c})}$ & 47 \\
\hline $\mathrm{BeP} / \mathrm{BES}+$ glass & $\begin{array}{c}(2.0 \pm 0.2) \text { to } \\
(4.6 \pm 0.4)\end{array}$ & $\begin{array}{l}(8.4 \pm 2.1) \text { to } \\
(15.1 \pm 4.2)\end{array}$ & This work \\
\hline
\end{tabular}

a) ATC-anthracene

b) Heterogeneous reactions of ATC on aerosol particles

c) The values were calculated from the data given in the literature 
Table 2. Tentatively identified products from heterogeneous reaction of BeP with ozone

(n)




\section{Supplementary Material}

Application of Direct Analysis in Real Time-Mass Spectrometry (DART-MS) to the Study of Gas-Surface Heterogeneous Reactions: Focus on Ozone and PAHs

Shouming Zhou*, Matthew W. Forbes, Jonathan P.D. Abbatt

Department of Chemistry, University of Toronto, Toronto, ON, M5S 3H6, Canada

* to whom correspondence should be addressed 


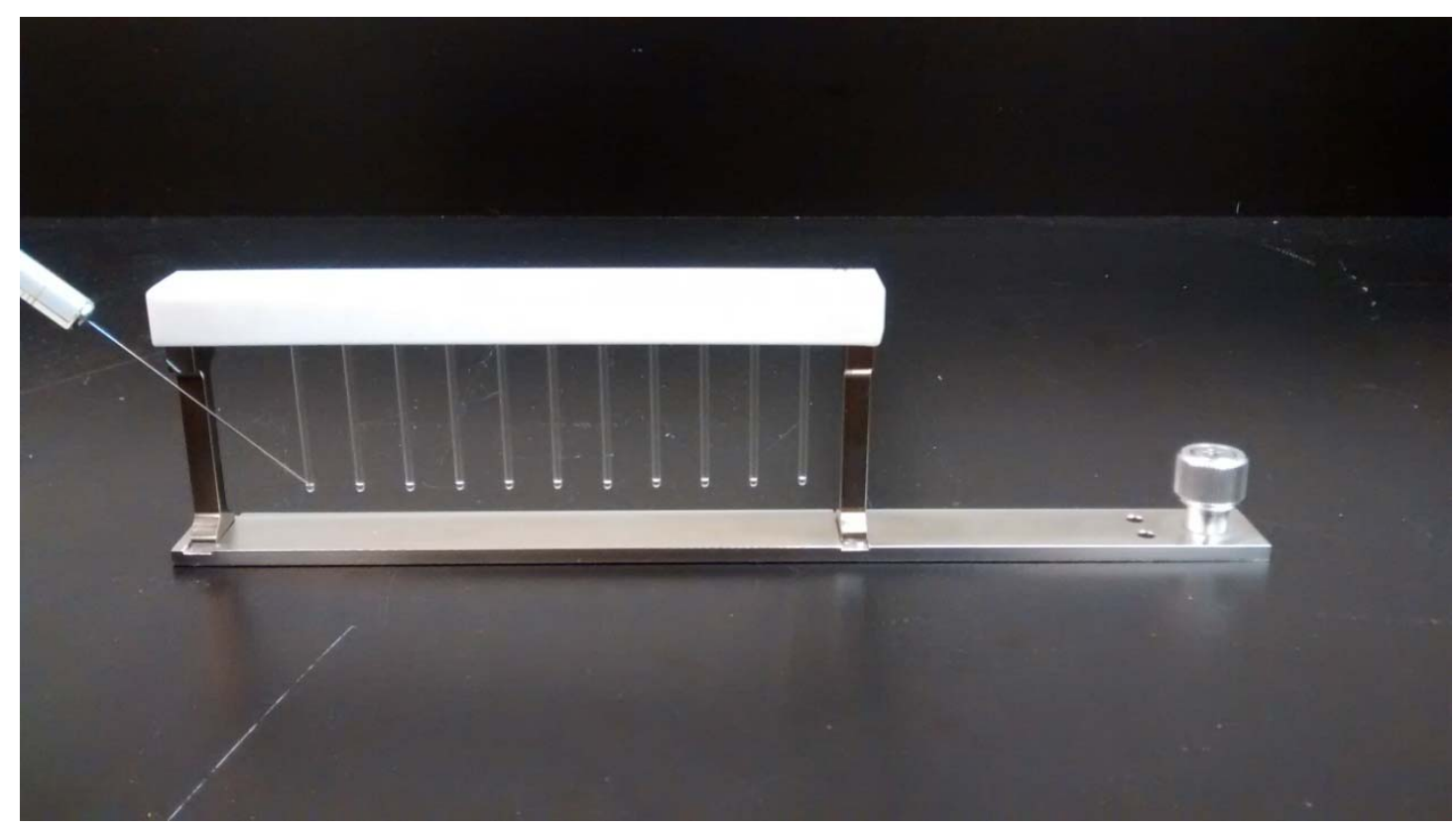

Figure S1. $1 \mu 1 \mathrm{BeP} / \mathrm{BES}$ solution was deposited on the sealed-end of glass capillaries

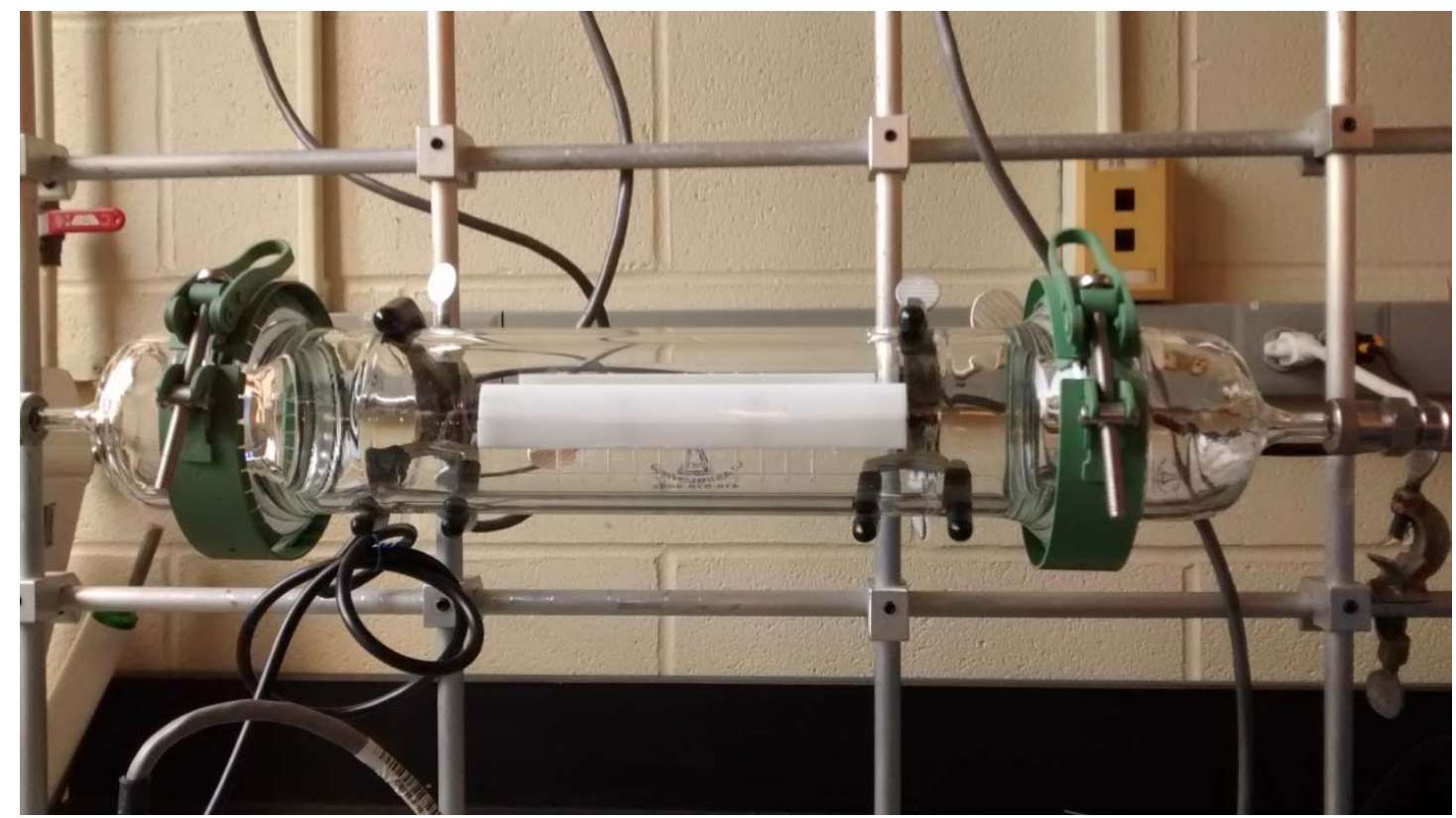

Figure S2. Oxidation of $\mathrm{BeP}$ with gas-phase ozone in a flow tube. 


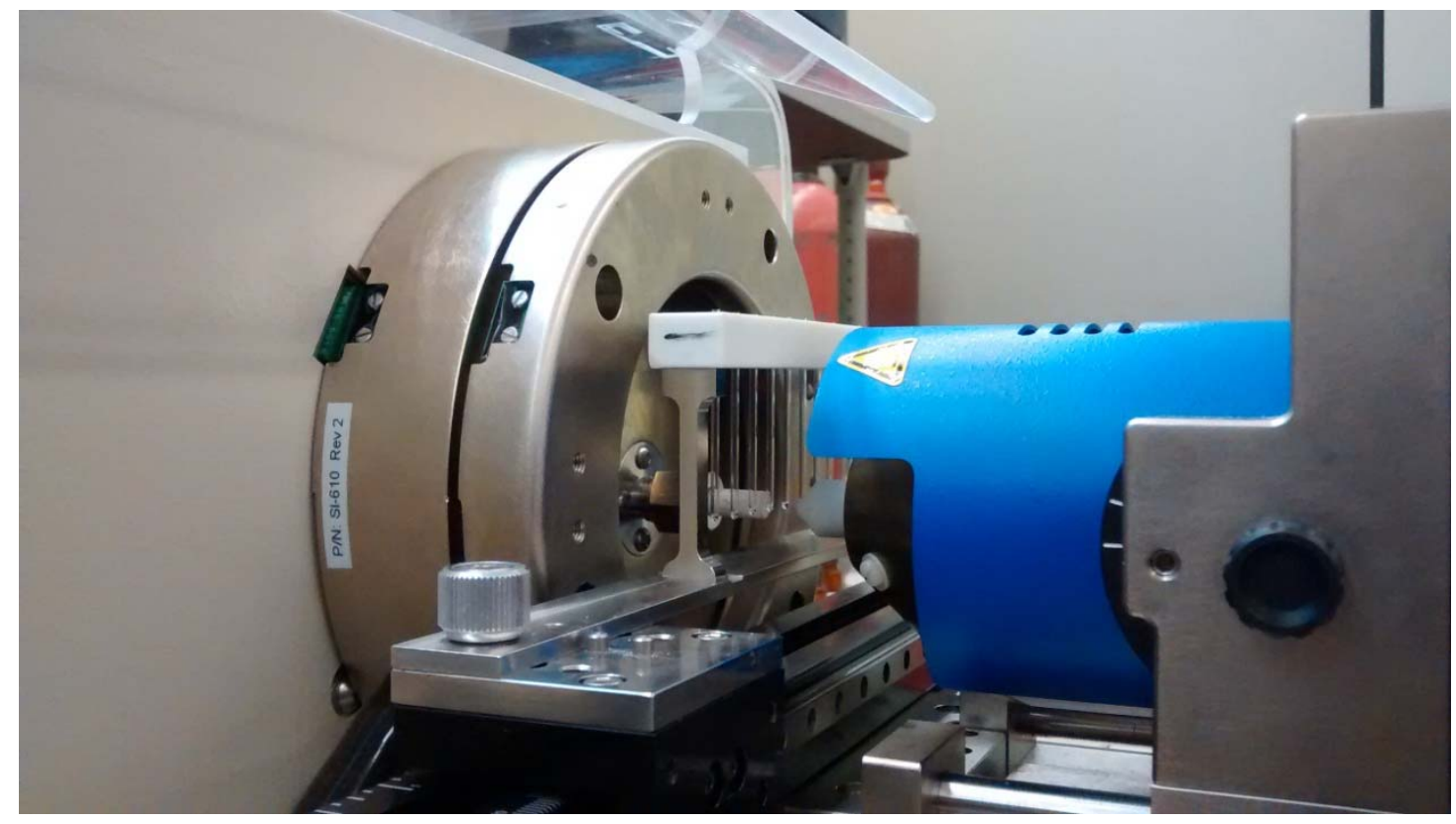

Figure S3. DART-MS analysis of BaP/BES samples on the capillaries.

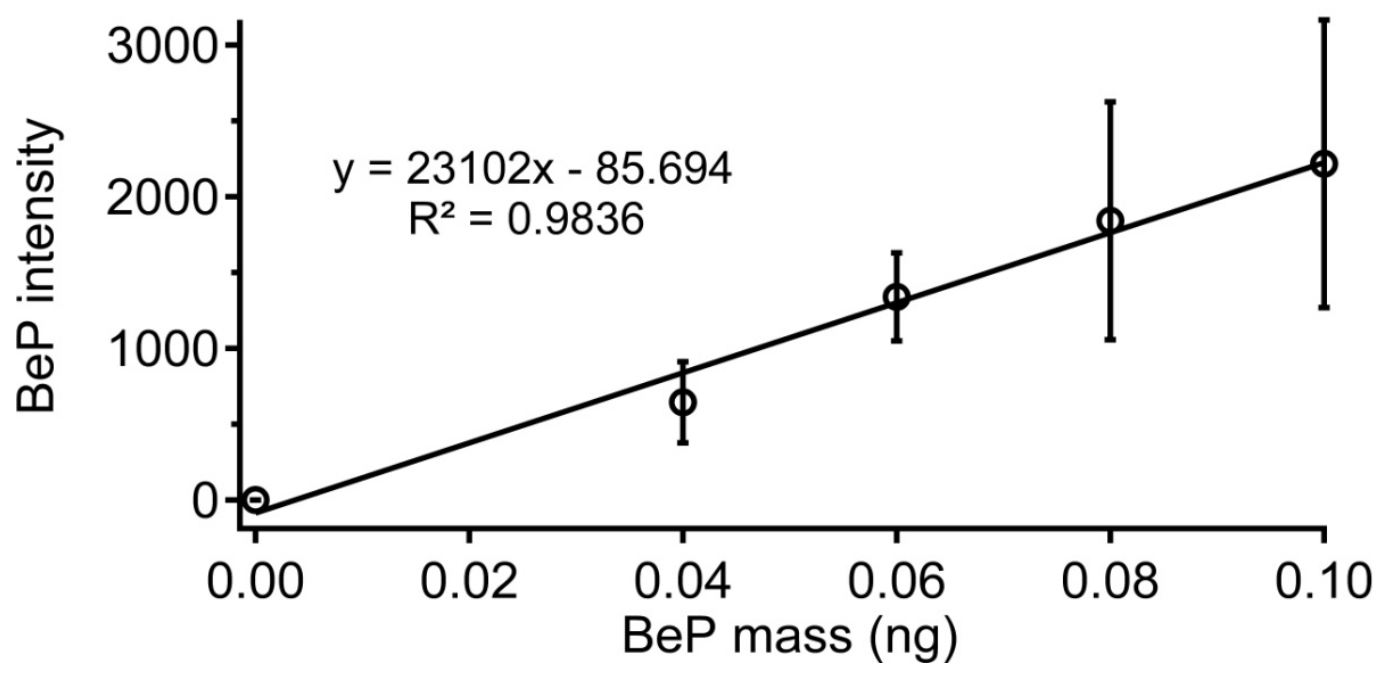

Figure S4. Calibration curve for determination of LOD of BeP ranging from 0-0.1ng on the capillaries 
Table of Contents Graphic (TOC)

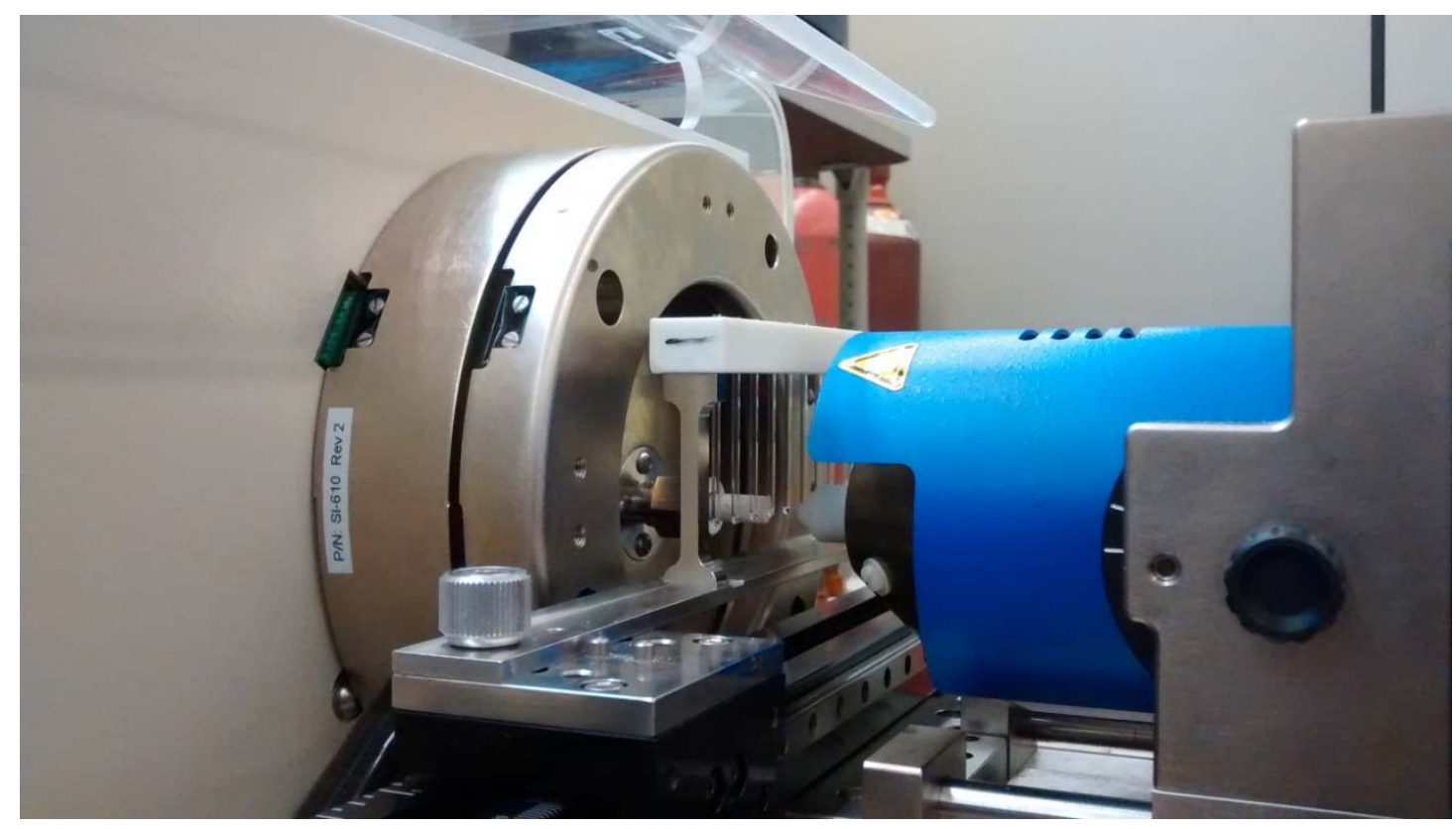

